\title{
RELATIONSHIP MARKETING ON THE INTERNET: BUILDING A LONG-TERM RELATIONSHIP WITH CUSTOMERS
}

\section{Elina Radionova-Girsa}

Faculty of Business, Management and Economics, University of Latvia, Aspazijas 5, Riga, Latvia E-mail: elinaradionova@gmail.com

\begin{abstract}
The purpose of the study is to find out the main approaches to the relationship marketing on the internet that could help companies to build a long-term relationship with their customers. Principal objectives are to find and analyse scientific literature on the topic; with statistical and empirical analysis to find out the main differences between relationship marketing in the traditional and internet dimension. The research methods of the paper are scientific literature theoretical analysis, statistical and empirical data analysis. The results of the research are both theoretical and practical. Using results companies will be able to share their customers seeing at what stage they are located and what further steps should be taken to achieve the desired result.
\end{abstract}

Keywords: relationship marketing, internet, customer behaviour, long-term relationships.

JEL Classification: M31.

\section{Introduction}

The fact that we live in the 21st century and how technology has become an integral part of our daily lives is beyond doubt. According to the Central Statistical Bureau of Latvia, every year $77 \%$ of the total population of Latvia is using the Internet on a regular basis (at least once a week) in 2016. The statistics for 5 years are shown below and are as follows: in 2012 there were $70.3 \%$ of the total population in Latvia who used the Internet regularly (at least once a year) using the computer / Internet at the beginning of the year, in 2013 the number of such users increased and became $71,2 \%$, in $2014-71.8 \%$, in $2015-74.9 \%$, and in $2016-77 \%$, in $2017-79 \%$.

As can be seen from the Figure 1, and as clearly shown in the graph, the number of Internet users has grown by $9 \%$ over the last six years. The author believes that this is a fast and steep increase, which means that companies must also strive to adapt to these market conditions such as Internet options, availability of products and services, fast delivery, etc. in order to reach their consumers. It has to be said that not only consumers but also companies are now often found on the Internet, regardless of industry.

Hearing words like interactive marketing from the beginning seems to be a completely new and unexplored concept. It should be said that such a statement is not quite correct. In the 80s of the last century, the explanation and essence of this phenomenon began to emerge. Then, the development of this marketing side began, pointing to the need to create interactions with consumers and build long-term relationships.

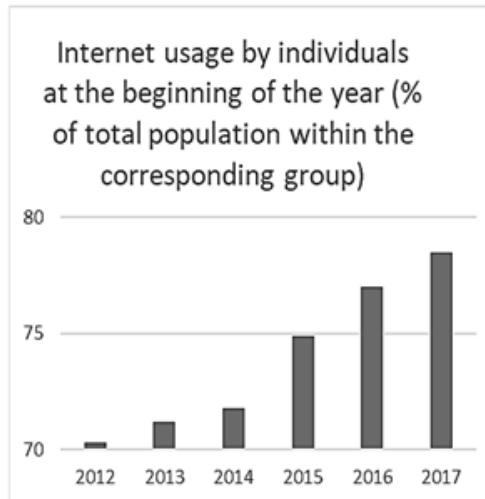

Figure 1. Internet usage by individuals at the beginning of the year (\% of total population within the corresponding group) (source: Central Statistical Bureau of Latvia)

Relationship Marketing was first defined in 1983 as a marketing activity that attracts, develops, maintains and improves interaction with consumers, which has changed the focus of marketing orientation, from short-term communication to long-term communication and inter-action with the consumer (Berry, 1983; Berry \& Parasuraman, 1991; Grönroos, 1994; Chiua, Hsiehb, Lic, \& Lee, 2005). 
Companies are trying to create interactive marketing (sometimes loyalty) programs to increase the level of interaction with the consumer, which in turn will increase the level of loyalty to the company and its products (Schiffman \& Kanuk, 2004). The main cornerstone of relationship marketing is the creation of a link between the company and its consumer (Roberts, Varki, \& Brodie, 2003). Various sources of literature can be counselled that this interaction also includes a financial, social and structural side (Lin, Weng, \& Hsieh, 2003). In any case, in the interaction with the consumer, one must not forget about the components of consumer behaviour (Gwinner, Gremler, \& Bitner, 1998).

The author puts forward that the purpose of the study is to find out the main approaches to the relationship marketing on the internet that could help companies to build a long-term relationship with their customers. The research methods of the paper are scientific literature theoretical analysis, statistical and empirical data analysis. The results will help not only to understand the impact of relationship marketing but also to apply the knowhow to both communications with customers and the company's strategy.

\section{Theoretical Analysis}

If companies want to move to the Internet dimension, it's necessary to understand that the Internet as a marketing channel is up-to-date, but it has its own peculiarities and differences from the understanding of the traditional marketing channels. In the Internet environment, the consumer has unique opportunities to quickly move between offers and stores, to look for alternatives and best practices that could satisfy his wishes as best as possible. However, it is assumed that the consumer needs to evaluate the product only after the information provided by the trader on the website, namely, the description of the image, description, another consumer, etc. It should be noted that the consumer, when deciding whether to buy, is also important for the overall appearance of the website and how convenient it is to navigate the website when looking for a product and its specification (Chiu, Wang, Fang, \& Huang, 2014; Hong, Thong, \& Tam, 2004; Kolesar \& Galbraith, 2000). As a matter of fact, the consumer sees only a picture with a description, from which he has to draw conclusions and make a decision to make a purchase. Perhaps the consumer will search for some feedback, ask for help and friends, but the main impact on him is first the first information available on the website. Of course, it is not necessary to say that if at the end the consumer receives a product that is not relevant to the image and description, he will not only be dissatisfied, but trust in the particular internet marketer will be low and there will be no desire to buy something again.

This is important not only for the sale of products but also for services on the Internet (Bilgihana \& Bujisic, 2015), such as hotel reservation, airline tickets, banking services. And only in the event of interaction with the consumer, he is ready to buy goods or services with a particular Internet merchant. In this case, the interaction will also be with the device itself and the home page (Griffith, Krampf, \& Palmer, 2001). The better the website design and the more convenient navigation, the more satisfied the consumer is in the purchase process (Floh \& Madlberger, 2013). The author fully agrees that the consumer needs to feel comfortable and free on the website so that interactions in the Internet environment take place as easily as possible and the consumer would have the desire not only to return to this Internet merchant and make repeated purchases but also to recommend this site to his relatives and friends.

Consumers are looking at the Internet for two types of activities - hedonistic and utilitarian shopping. Hedonic shopping is focused on the entertainment process from the use of the website, such as virtual tours, pictures, and more. In turn, utilitarian shopping is geared towards the end result - a purchase that was made to reach a specific goal, for example, price comparison, finding a better service, etc. (O’Brien, 2010)

The main difference between these directions is that with consumers buying hedonistic entertainment, satisfaction and enjoyment through the Internet, but in the utilitarian case, he has a specific goal to be achieved in the buying process. Consequently, website owners need to adapt their site to both categories of consumers, although those who are looking for entertainment, and those who have a specific purpose to find everything they need there.

The main utilities can be marked by availability, the ability to effectively search for the necessary information, providing the product or service with full information. Consumers who are looking for purely utilitarian features, site designers need to provide informative design, easy and transparent use (Wolfinbarger \& Gilly, 2003). In its turn, the hedonic features are such as enjoyment, entertainment, fantasy, and promotion of 
making a purchase (Childers, Carr, Peck, \& Carson, 20011). Therefore, creators need to use moving (animated) images, pay close attention to colour choices, sound, social component and aesthetic appearance (Bilgihana \& Bujisic, 2015). Hedonic features also include the features of the game to stimulate interest in the consumer to visit the website several times for gambling (Hamari, Koivisto, \& Sarsa, 2014).

The author emphasizes that the need to understand what kind of consumer is important to him is important because it is his consumer's knowledge of how to build successful communication with him. Undoubtedly, you can create your own website so that it's easy to have both categories in place, but sometimes it's hard to put up entertaining content on industry-specific websites, so there's a need for some kind of consumer orientation.

If companies want to move to the Internet dimension, it's necessary to understand that the Internet as a marketing channel is up-to-date, but it has its own peculiarities and differences from the understanding of the traditional marketing channels. In the Internet environment, the consumer has unique opportunities to quickly move between offers and stores, to look for alternatives and best practices that could satisfy his wishes as best as possible.

\section{Statistical Data}

European statistics show Internet usage and, of course, the rapid growth of Internet commerce. For example, in 2015, 516 million people across Europe, accounting for $75 \%$, used the Internet in their everyday lives. Of which, 296 million were those who bought on the Internet. The Internet marketing market has grown by $12 \%$, indicating that the market is very advanced and is developing quite rapidly (Global B2C E-Commerce Report, 2016).

Speaking about the territory of Latvia, the second Gemius study on the e-commerce market in Latvia is available and within it, it was revealed that in Latvia, compared to 2016, the opportunity to shop on the Internet is used by 5 percent more users. Similarly to the results of the previous year, both women (53 percent) and men (47 percent) are equally active on the Internet, while almost half, or 48 percent of all users who shop online, are 2544 years old (Gemius Latvija Database).

Interestingly, similar data is available on women (51 percent) and men (49 percent) who say they have not bought but are planning to buy goods or services online in the near future. By contrast, when responding that they do not intend to buy any goods or services on the Internet, only 46 percent of the respondents are women, while men account for 54 percent.

Most often, online stores are used by people with an average net income of 255 to 499 euros (30 percent) per household member. In this group also the most users have admitted that they have not bought anything in the last year, but in the near future, they plan to do this (35 percent).

Most of those who buy online use the most frequently used Latvian e-commerce sites (92 percent), but also use Chinese e-commerce pages (45 percent) for this purpose.

Among top-of-minded e-commerce sites, the most popular is ebay.com (32 percent), followed by the Asian e-commerce giant aliexpress.com (30 percent) and the first trio completes 220.lv (29 percent).

The study is based on a specialized internet survey - gemiusAdHoc. The research is based on data obtained through spin-off internet questionnaires that were displayed randomly by Internet users in the largest news sites in Latvia: tvnet.lv, delfi.lv, eradio.lv, andelemandele.lv, city24.lv, lsm.lv, brivbridis.lv, sportacentrs.lv, gismeteo.lv, kurpirkt.lv, salidzini.lv and jauns.lv. The study was conducted between May 18th and 24th, 2017, and 2787 respondents were interviewed in the age group of 18-74 years.

The author wishes to draw attention to the fact that the market that is transferred to the internet environment is very viable and entrepreneurs need to think about how to better perform their activities in it. Because, of course, access to consumers, communication with them will be different in these environments.

\section{Discussion}

One of the key principles of the concept of relationship marketing is to consider the value of the client to the community throughout his life in her life. From the point of view of target interaction, which means that the focus of the company to maximize the income of one client during this time, firstly, increasing customer cooperation with the company, and secondly, promoting the buyer more active consumption of its products and services.

There is a point that all transactions carried out by the consumer should be taken into account in relation to one single consecutive chain of events. It should be pointed out that a long-term 
cooperation with consumers needs to be made using the maximum number of products and services per customer throughout its life cycle, which greatly increases its value to the company. Thus, looking at the value of the consumer in the organization is related to the term, such as the consumer's lifecycle.

There are several approaches to formalizing the consumer's lifecycle. For example, Grenroos $\mathrm{K}$. proposed the following categorization system that is shown in the Figure 2.

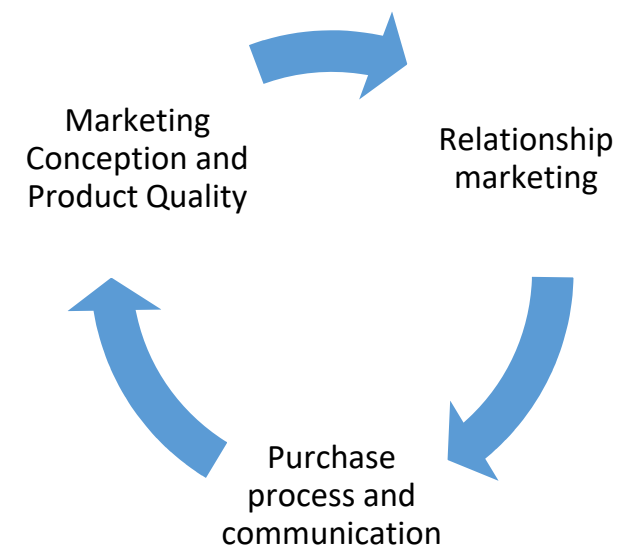

Figure 2. Consumer Lifecycle Approaches (source: The author created a picture by Grenroos (1990))

Following this model, the relationship building process with the consumer begins even with the emergence of interest in the company's products and services. It should be noted that from the point of view of the interaction of marketing, all activities carried out at this stage need to provide the buyer with the necessary information and have a positive impact on interaction so that he is interested not only in the product but also about the company and its activities.

After the buyer's introduction of the company's offer, the second phase of the life cycle begins the buying process. This stage is characterized by the fact that the buyer compares his impressions with the acquired experience of interactions with the company, transferring his past experience to the future. At this stage, it is necessary to begin to create consumer loyalty to the company, which can first of all be met by satisfying all the client's functional needs. This phase is characterized by the fact that the client gains experience in interacting with the company at all contact points and experience related to the quality of his needs satisfaction. Important factors here are the quality of products and services, as well as the extent to which the company will be able to interact with the consumer.

If the customer's experience is positive and the company succeeded in achieving its first goal in developing long-term interactions, the third step begins - the purchasing process when the product or service is used. From an interactive marketing perspective, this development phase in the consumer's life cycle is most saturated with various company offers aimed at increasing customer value-added, offering customer cards, discounts for the next purchase, etc.

The author of the paper points out that the research is directly related to the Internet environment, as there are now many companies acting. Realizing that consumer behaviour, satisfaction and online loyalty are different from the traditional environment, companies will be able to adapt their strategy directly to the Internet environment. In the future study, the author will examine factor analysis factors that affect consumer loyalty and interactive marketing in the Internet environment.

\section{Conclusions}

Relationship marketing is a relatively new marketing focus whose main goal is to establish longterm relationships with mutually beneficial grounds. Interaction is not only between business and consumer, it also occurs in dimensions such as the company and its interactions with internal and external actors.

The company's focus on personalized customer service is the cornerstone of its success for targeted customer interaction. This means, firstly, the use of a narrowly focused communication strategy and, second, the adaptation of the products and services developed to the needs and expectations of consumers.

The economic rationale for an interactive marketing strategy that focuses on long-term interaction with its customers and customer satisfaction focuses on more profitable customers or client segments, so companies can improve targeting and efficient use of their budget.

If companies want to move to the Internet dimension, it's necessary to understand that the Internet as a marketing channel is up-to-date, but it has its own peculiarities and differences from the understanding of the traditional marketing channels. In the Internet environment, the consumer has unique opportunities to quickly move between offers and stores, to look for alternatives and best practices that could satisfy his wishes as best as possible. 
Consumers are on the Internet looking for two different types of activities - hedonic and utilitarian shopping. Hedonic shopping is focused on the entertainment process from the use of the website, such as virtual tours, pictures, and more. In turn, utilitarian shopping is geared towards the end result - a purchase that was made to reach a specific goal, for example, price comparison, finding a better place to provide services, etc.

As the main utilitarian peculiarities, it can be noted availability, the ability to effectively search for the necessary information, providing the product or service with full information. Consumers who are looking for purely utilitarian features, site designers need to provide informative design, easy and transparent use. In its turn, the hedonic features are such as enjoyment, entertainment, fantasy, and promotion of making a purchase. Therefore, creators need to use moving (animated) images, pay close attention to colour choices, sound, social component and aesthetic appearance. Hedonic features also include the features of the game to stimulate interest in the consumer to visit the website several times for gambling.

Undertakings on the Internet can not overlook the speed and quality of the business. Internet facilities provide prerequisites that enable the company to reach its consumer quickly and efficiently. The author wishes to emphasize that this kind of communication must be of a higher quality. Only then will the consumer wish to establish a long-term relationship with the company.

Statistical data both in Europe and in Latvia shows that internet sales have increased rapidly in recent years. In 2015, 516 million people across Europe, accounting for $75 \%$, used the Internet in their everyday lives. Of which, 296 million were those who bought on the Internet. That in Latvia, compared to 2016, the opportunity to shop on the Internet is used by 5 percent more users.

The research is directly related to the Internet environment, as there are now many companies acting. Realizing that consumer behaviour, satisfaction and online loyalty are different from the traditional environment, companies will be able to adapt their strategy directly to the Internet environment. In the future study, the author will examine factor analysis factors that affect consumer loyalty and interactive marketing in the Internet environment.

\section{Disclosure Statement}

I declare that I do not have any competing financial, professional, or personal interests from other parties.

\section{References}

Babin, B. J., Darden, W. R., \& Griffin, M. (1994). Work and/or fun: measuring hedonic and utilitarian shopping value. Journal of Consumer Research, 20(4), 644-656. https://doi.org/10.1086/209376

Berry, L. L. (1983). Relationship marketing. In L. L. Berry, L. Shostack, \& G. Upah (Eds.), Emerging perspectives on service marketing (pp. 25-28). American Marketing Association, Chicago (IL).

Berry, L. L., \& Parasuraman, A. (1991). Marketing service competing through quality. The Free Press, New York.

Bilgihana, A., \& Bujisic, M. (2015). The effect of website features in online relationship marketing: A case of online hotel booking. Electronic Commerce Research and Applications, 14(4), 222-232. https://doi.org/10.1016/j.elerap.2014.09.001

Central Statistical Bureau of Latvia. (2018). Retrieved from http://data.csb.gov.lv/pxweb/lv/zin/zin_datoriz 01ikt_datori_01_iedz/ITM0040.px/table/table ViewLayout2/?rxid=cdcb978c-22b0-416a-aaccaa650d3e2ce0

Childers, T. L., Carr, C. L., Peck, J., \& Carson, S. (2001). Hedonic and utilitarian motivations for online retail shopping behaviour. Journal of Retailing, 774(4), 511535. https://doi.org/10.1016/S0022-4359(01)00056-2

Chiu, C. M., Wang, E. T., Fang, Y. H., \& Huang, H. Y. (2014). Understanding customers' repeat purchase intentions in B2C e-commerce: the roles of utilitarian value, hedonic value and perceived risk. Information Systems Journal, 24(1), 85-114. https://doi.org/10.1111/j.1365-2575.2012.00407.x

Chiua, H. C., Hsiehb, Y. C., Lic, Y. C., \& Lee, M. (2005). Relationship marketing and consumer switching behaviour. Journal of Business Research, 58(12), 16811689.

https://doi.org/10.1016/j.jbusres.2004.11.005

Floh, A., \& Madlberger, M. (2013). The role of atmospheric cues in online impulse-buying behaviour. Electronic Commerce Research and Applications, 12(6), 425-439. https://doi.org/10.1016/j.elerap.2013.06.001

Gemius Latvija Database. (2018). Retrieved from http://www.gemius.lv/all-reader-news/gemius-publice-jaunako-latvijas-e-komercijas-petijumu.html

Global B2C E-Commerce Report. (2016). https://www.ecommercewiki.org/wikis/www.ecommercewiki.org/images/5/56/Global_B2C_Ecommerce_Report_2016.pdf

Grenroos, C. (1990). Service marketing. Lexingston: Lexingston books. $567 \mathrm{p}$.

Griffith, D. A., Krampf, R. F., \& Palmer, J. W. (2001). The role of interface in electronic commerce: consumer involvement with print versus on-line catalogs. International Journal of Electronic Commerce, 5(4), 135-154. https://doi.org/10.1080/10864415.2001.11044219

Grönroos, C. (1994). From marketing mix to relationship: towards a paradigm shift in marketing. Management Decision, 32(2), 4-21. https://doi.org/10.1108/00251749410054774 
Gwinner, K. P., Gremler, D. D., \& Bitner, M. J. (1998) Relational benefits in service industries: the customer's perspective. Journal of the Academy of Marketing Science, 26(2), 101-114. https://doi.org/10.1177/0092070398262002

Hamari, J., Koivisto, J., \& Sarsa, H. (2014). Does gamification work? - A literature review of empirical studies on gamification. In Proceedings of the $47^{\text {th }}$ Hawaii International Conference on System Sciences, 6-9 January 2014, Hawaii, USA. https://doi.org/10.1109/HICSS.2014.377

Hong, W., Thong, J. Y. L., \& Tam, K. Y. (2004). The effects of information format and shopping task on consumers' online shopping behavior: a cognitive fit perspective. Journal of Management Information Systems, 21(3), 149-184.

https://doi.org/10.1080/07421222.2004.11045812

Kolesar, M. B., \& Galbraith, R. W. (2000). A services-marketing perspective on e-retailing: implications for e-retailers and directions for further research. Internet Research, 10(5), 424-438.

https://doi.org/10.1108/10662240010349444
Lin, N. P., Weng, J. C. M., \& Hsieh, Y. C. (2003). Relational bonds and customer's trust and commitment - a study on the moderating effects of web site usage. The Service Industries Journal, 23(3), 103-124. https://doi.org/10.1080/714005111

O'Brien, H. L. (2010). The influence of hedonic and utilitarian motivations on user engagement: the case of online shopping experiences. Interacting with Computers, 22(5), 344-352. https://doi.org/10.1016/j.intcom.2010.04.001

Roberts, K., Varki, S., \& Brodie, R. (2003). Measuring the quality of relationships in consumer services: an empirical study. European Journal of Marketing, 37(1/2), 169-196. https://doi.org/10.1108/03090560310454037

Schiffman, L. G., \& Kanuk, L. L. (2004). Consumer behaviour ( $8^{\text {th }}$ ed.). Pearson Prentice Hall, Upper Saddle River (NJ).

Wolfinbarger, M., \& Gilly, M. C. (2003). eTailQ: Dimensionalizing, measuring and predicting etail quality. Journal of Retailing, 79(3), 183-198. https://doi.org/10.1016/S0022-4359(03)00034-4 